\title{
AC 2009-82: WEST AFRICAN TECHNOLOGY, EDUCATION, AND RECIPROCITY IMPLEMENTATION IN BENIN
}

\section{Bradley Striebig, James Madison University}

Dr. Bradley A. Striebig is an associate professor of Engineering at James Madison University. He has a Ph.D. in Environmental Engineering from Penn State University, where he was the head of the Environmental Technology Group at the Applied research Laboratory. Prior to accepting a position to develop the engineering program at James Madison University, Brad was a faculty member in the Civil Engineering department at Gonzaga University. He has worked on various water projects throughout the US and in Benin and Rwanda.

\section{Susan Norwood, Gonzaga University}

Susan Norwood is a Professor of Nursing at Gonzaga University. She earned her Bachelor of Science in Nursing from Pacific Lutheran University, a Master's in Nursing from the University of Washington, and a certificate as a Women's Health Nurse Practitioner from Harbor-UCLA Medical Center. Her Doctorate in Educational Leadership is from Gonzaga University. She has been a nurse educator for 23 years and has been teaching at GU since 1991. She has taught a wide variety of courses to both graduate and undergraduate nursing students and has authored several textbooks. 
Abstract

WATER (West African Appropriate Technology, Education, and Reciprocity) is an interdisciplinary course with a three-part focus: cross cultural training and in-depth study of West African culture, study of health conditions and health promotion in developing countries, and epidemiological research designs and their practical application using appropriate technologies for eradicating water-related illnesses in Benin, West Africa. Students worked in multidisciplinary project teams and used course content as the foundation for developing and implementing a water development project. This program has significantly impacted the community at the Songhai Center in Benin and the students that participated in every aspect of the project.

\section{Introduction}

Benin is a West African country of approximately 8.5 million people, nearly a third of whom lack access to potable water. ${ }^{1}$ Mortality rates, especially for infants and children in Benin, are much higher than mortality rates in the developed world. ${ }^{2}$ Centralized water treatment, like we have in the States, is not a feasible option for community drinking water in Benin because it is extremely expensive to construct and maintain.

In rural Benin, the primary ways that people obtain clean drinking water are by boiling water or purchasing imported bottled water. Boiling water requires wood and native vegetation, depleting local resources and emitting smoke into households and the atmosphere. Buying bottled water is not a cost-effective, long-term solution for low-income populations. Furthermore, the links between contaminated drinking water, sanitation, and disease are not understood by all of Benin's population. As a result, most people in Benin drink water that does not meet the standards set by the World Health Organization (WHO). ${ }^{3,4}$

The water in much of Benin is contaminated with bacteria and viruses. ${ }^{5}$ These are the major concerns in Benin drinking water because of their impact on human health. Typhoid fever, amoebic dysentery, schistosomiasis, and cholera are just a few of the diseases spread by contaminated water. Nearly 17 percent of children born in Benin die before the age of five. ${ }^{3}$

Porto-Novo is a colonial era city with a population of about 250,000 inhabitants. ${ }^{6}$ The Songhai Center is headquartered in Porto-Novo, the capital of Benin. In a visit to Benin in 2004, Father Nzamujo Godfrey, director of the Songhia Center, stated the need for a low-cost, sustainable Point-of-use drinking water filter. Much of Benin is blessed with access to water through shallow wells or surface waters, however human and animal wastes contaminate the water. While treated water is available in some instance, less than 10 percent of the population has treated water piped into their homes. Bagged and bottled water can be purchased in the marketplace, but this practice is expensive, unsustainable and can sometimes be tampered with, so that the water can unknowingly become contaminated. The preferred treatment technology for the area would be a cost-effective point-of-use technology.

For several years, students evaluated point-of-use water filter technologies that would be appropriate for implementation at the Songhai center. The ceramic filter technology was selected for potential implementation. However, the existing mission and capacity of the Songhai Center had to be expanded to properly transfer the technology. The expanded needs in water and its 
relationship to human health, was essentially an education need. The same subject was of interest to many students in engineering, nursing, and other academic majors.

Providing the technology to implement point-source water treatment in the community will likely decrease childhood and maternal mortality rates in Benin. ${ }^{5}$ This background, along with an assessment trip to Benin in 2004, provided the initiative between faculty, Engineers Without Borders USA (EWB-USA), Potters For Peace (PFP), and the Songhai Center to propose a manufacturing facility for drinking water filters in Benin. Community-focused projects, such as this one, directly address the eight Millennium Development Goals set forth by the UN. ${ }^{7}$

It is widely recognized that more than engineering and health care initiatives are needed to improve the living conditions in Benin. The United Nations Millennium Development Goals set forth inter-related goals that address the foundation of a society's needs. ${ }^{7}$ While these goals go well beyond what one simple program can address. The goals do prescribe important connections in international development, in the hopes that development can be sustainable.

Over a period of three years, a service learning-based project was developed to address some of the needs in Benin, while simultaneously meeting the needs of academic programs for study abroad opportunities.

Upon further reflection and discussion between Father Nzamujo, university faculty and university administration, a service-based study abroad class was developed. The West African Technology, Education and Reciprocity (WATER) classes was developed as an interdisciplinary study abroad course that addressed the needs of the students, the Songhai Center, and the people of Benin.

\section{Problem statement}

Study abroad opportunities have become an expectation in higher education. More than half of incoming students intend to have some type of study abroad experience during their undergraduate education. In addition, ABET has stated that engineers exhibit an awareness of global conditions and circumstances that may influence the design process. Finally, study abroad programs may take students outside of their typical comfort zones, allowing them to stretch and grow in ways that are just not possible to simulate on campus.

However, in fields with very stringent accreditations schedules and restricted course loads, study aboard programs are difficult to fit into a student's schedule. This is traditional true in both engineering and nursing curriculums. Another similarity between nursing and engineering are that both are trying to diversify the student body. One method to attract under-represented groups in engineering has been to offer humanistic programs as a club activity, such as Habitat for Humanity projects, Engineers Without Borders clubs, and other programs that allow engineering students to connect the engineering process to the people they are serving. ${ }^{8}$

This paper will address the design and outcomes associated with the implementation of the service-based project in the course. The technological effectiveness will be discussed, as well as the shortcomings of the implementation process. (Evaluation of the course development and other educational outcomes are discussed in a separate paper. ${ }^{9}$ ) 


\section{Program description}

Engineering students could take part in various steps in the project-based program, as illustrated in Table 1. The elements of the project were distributed through senior design capstone courses and the interdisciplinary study abroad course. The study abroad course was taught as a 10 -week on-line didactic portion that was followed immediately with the two weeks immersion experience.

Table 1: Distribution of the project-based curriculum

\begin{tabular}{|c|c|c|c|c|c|c|c|}
\hline \multirow{2}{*}{$\begin{array}{l}\text { Course } \\
\text { Name }\end{array}$} & \multirow[t]{2}{*}{ Component } & \multicolumn{4}{|c|}{ Hours (estimated) } & \multicolumn{2}{|c|}{ Participation } \\
\hline & & $\begin{array}{l}\text { Fall } \\
\text { Term }\end{array}$ & $\begin{array}{l}\text { Spring } \\
\text { Term }\end{array}$ & $\begin{array}{l}\text { Summer } \\
\text { On-Line }\end{array}$ & $\begin{array}{l}\text { Immersion } \\
\text { Experience }\end{array}$ & $\begin{array}{c}\text { Multi- } \\
\text { disciplinary }\end{array}$ & $\begin{array}{l}\text { Songhai } \\
\text { Partners }\end{array}$ \\
\hline $\begin{array}{l}\text { Senior } \\
\text { Design } 1\end{array}$ & $\begin{array}{l}\text { Project Based } \\
\text { Design }\end{array}$ & 45 & & & & $\begin{array}{l}\text { Some } \\
\text { Groups }\end{array}$ & No \\
\hline $\begin{array}{l}\text { Senior } \\
\text { Design } 2\end{array}$ & $\begin{array}{l}\text { Project Based } \\
\text { Design }\end{array}$ & & 45 & & & $\begin{array}{l}\text { Some } \\
\text { Groups }\end{array}$ & No \\
\hline \multirow[t]{8}{*}{ WATER } & Didactic & & & 30 & & Yes & No \\
\hline & $\begin{array}{l}\text { Intercultural } \\
\text { Communication }\end{array}$ & & & & 4 & Yes & Yes \\
\hline & Water Analysis & & & & 4 & Yes & Yes \\
\hline & Water Filtration & & & & 8 & Yes & Yes \\
\hline & $\begin{array}{l}\text { Health } \\
\text { Education }\end{array}$ & & & & 4 & Yes & Yes \\
\hline & First Aid & & & & 4 & Yes & Yes \\
\hline & $\begin{array}{l}\text { Discussion/ } \\
\text { Reflection }\end{array}$ & & & & 12 & Yes & Yes \\
\hline & $\begin{array}{l}\text { History and } \\
\text { Culture }\end{array}$ & & & & 20 & Yes & Yes \\
\hline
\end{tabular}

Preparation for the service learning process began several years earlier, in 2004. The service learning objectives were incorporated into engineering senior design projects from 2004 through 2007. As part of these projects, students tested and evaluated different technologies. They then optimized the process for the technology transfer and practiced teaching the process to other students as noted in Table 2.

Students carried out fundraising activities for two years in order to raise the monies necessary to transfer the technology and supplies for the Songhia Center. This fundraising effort was critical for obtaining the supplies for the manufacturing and analytical processes. In an effort to reduce shipping costs, most all supplies were packaged and carried on in checked luggage with the students' on-board the flights. This was the only secure way to ensure we would have all the supplies necessary for the technology transfer and also resulted in considerable savings compared to the expense of shipping the supplies separately. 
Table 2: Objectives of senior design projects from 2004 to 2007

\begin{tabular}{|l|l|c|}
\hline \multicolumn{1}{|c|}{ Objective } & \multicolumn{1}{|c|}{ Outcome } & Year \\
\hline $\begin{array}{l}\text { Research available point-of- } \\
\text { use treatment technologies }\end{array}$ & $\begin{array}{l}\text { Selected ceramic filter technology for the } \\
\text { application }\end{array}$ & 2004 \\
\hline $\begin{array}{l}\text { Purchased and } \\
\text { demonstrated ceramic filter } \\
\text { manufacturing technology }\end{array}$ & Learned how to make the filters & 2005 \\
\hline Water quality analysis & $\begin{array}{l}\text { Learned simple low-cost techniques to test } \\
\text { drinking water quality }\end{array}$ & $2005-2007$ \\
\hline Test ceramic filters & $\begin{array}{l}\text { Verified the technology met WHO criteria by } \\
\text { removing biological pollutants }\end{array}$ & $2005-2007$ \\
\hline $\begin{array}{l}\text { Optimize manufacturing } \\
\text { process for technology } \\
\text { transfer }\end{array}$ & $\begin{array}{l}\text { 1. created recipe for filters } \\
\text { 2. learned hand mixing techniques for } \\
\text { manufacturing filters } \\
\text { developed a collapsible portable press } \\
\text { for airline compliance }\end{array}$ & $2006-2007$ \\
\hline Test manufacturing process & $\begin{array}{l}\text { Documented manufacturing process and } \\
\text { determined supply needs }\end{array}$ & 2007 \\
\hline $\begin{array}{l}\text { Teach other students to } \\
\text { make water filters }\end{array}$ & $\begin{array}{l}\text { Learned how to train people to make the water } \\
\text { filters }\end{array}$ & 2007 \\
\hline
\end{tabular}

For proper technology transfer, regular communication with the Songhai Center was required to prepare the site for the facility prior to our arrival. For instance, the Songhai Center had to identify and clear a location for the work to be done prior to the visit. In addition, the Songhai Center had to obtain and dry approximately 500lbs of clay prior at least three weeks prior to our visit (to allow for the drying time). This was in addition to preparing the facilities in which we would be housed. Prepayment for the services that the Songhai Center provided was essential for the logistics to be incorporated prior to our arrival. Of course prepayment entails some risk, so it is important to have good communication and trust in the project partner prior to implementation of a large group visit to Benin.

Experience in Benin

One of the keystones in a successful service-learning project is to create mutual respect between project partners. This project created an ideal condition for creating this respect.

The transfer of the ceramic filter technology involved training the Songhai staff to make the water filters. The training procedures followed the watch - do - teach method. The first step in the process was to sift the clay and sawdust that had been gathered prior to the group's arrival. This process literally entailed getting everyone's hands dirty. The visual cues created by working with our hands in the Benin soil showed that we were serving the staff at the Songhai Center.

This step was to be crucial in how we were viewed as a group by our project partners. Several people from the Songhai Center stated the importance of visually showing what we hoped to do and being willing to get dirty ourselves first as a very important step in building a partnership. It was very important to the Songhai Center staff that we were not just verbally issuing instruction; 
the importance of working side-by-side with the staff during the teaching process cannot be overstated.

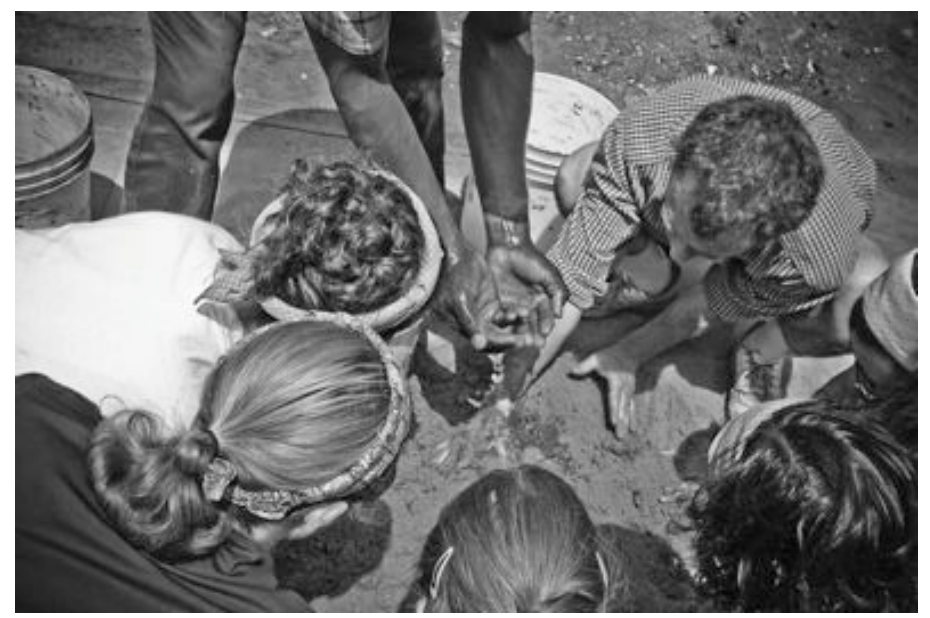

Figure 1: Getting everyone's hands dirty provided an important visual and cultural lesson that impacted the reception of the group by the local community at the Songhai Center.

After the first training session, we set aside time to work on language development skills. This provided an opportunity for a more relaxed atmosphere and also allowed students and Songhai staff to become more comfortable with one another. Some basic language skills were transferred during this time: College students taught English language skills to the Songhai staff and French and Fongbe (the local language) were taught by the Songhai staff to the students in the program. The language session allowed both groups to be more comfortable communicating with each other. Increasing the comfort level of staff and students allowed for more effective knowledge and technology transfer.

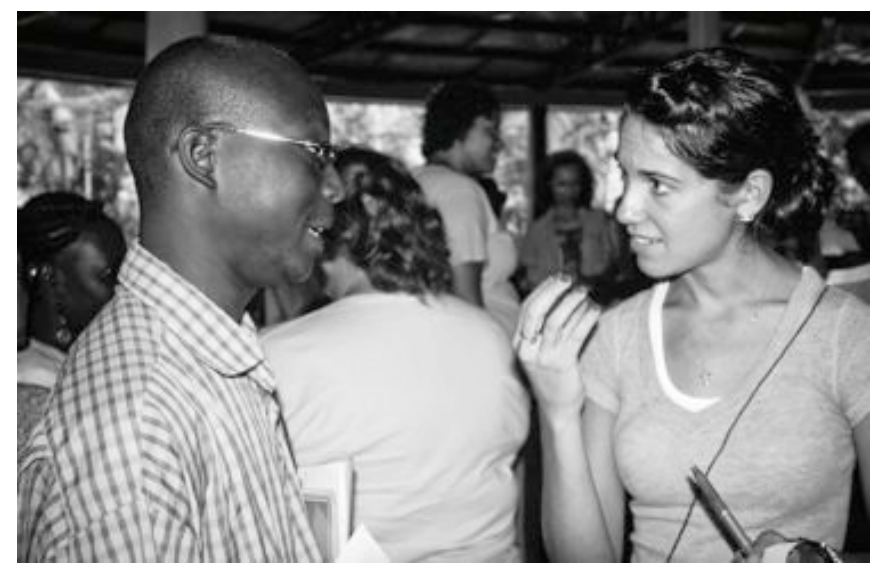

Figure 2: Language lessons provided an opportunity to improve communication between groups and allowed both groups to take on the roles of instructor and student. 
After demonstrating the process, the Songhai staff repeated the process by taking the lead and allowing the students in the study abroad program to assist. Finally, the staff that was originally trained in the filter manufacturing process was asked to train additional staff with the assistance and guidance of faculty from the study abroad program. Students were also engaged in teaching the water quality analysis tests that could be used to identify contaminated water sources that needed to be treated and also to test the water filters that were being manufactured.

Service learning project outcomes

The Songhai Center-manufactured approximately 400 ceramic water filters during the first year as a result of the service learning technology transfer program. The pride in the new skills of the Songhai staff was evident (see Figure 3) and articulated by many of the students in the program. The Songhai Center sold approximately 60 filters in the first year. This was partly due to startup lessons, climatic considerations, and a conscious decision to build up an inventory for supply of the filters prior to developing a marketing plan. Also during this start-up plan, several manufacturing issues were identified and are still in the process of being addressed.

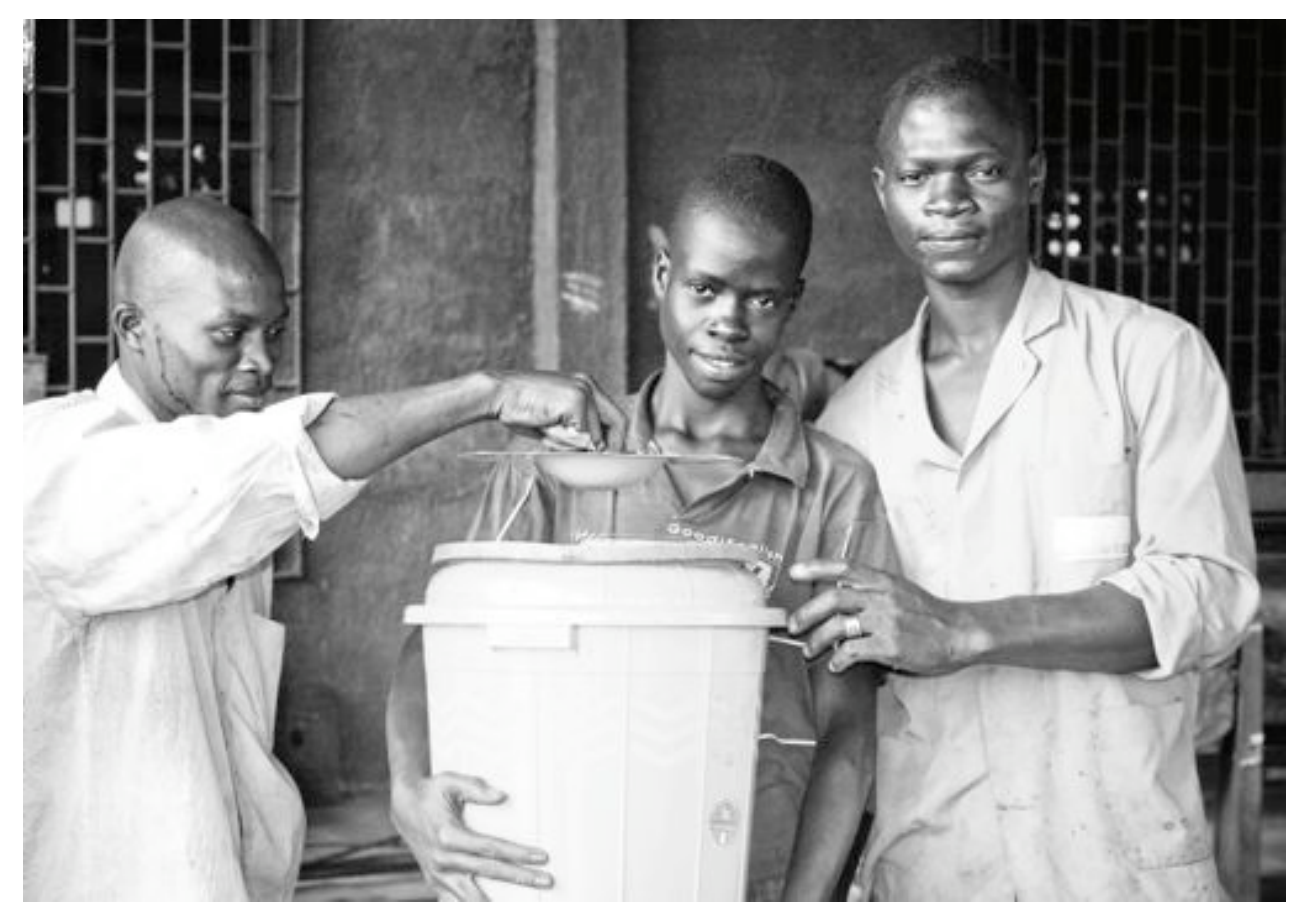

Figure 3: Technology transfer was accomplished when the Songhai Center staff took ownership of the product they had created.

The manufacturing status was verified in the second class trip to the Songhai Center in 2008. During the follow-up visit in 2008, the Songhai staff taught the study abroad students how to make the water filters. This created a similar atmosphere of service and community between Songhai Center staff and program students. It also allowed for the faculty members to review the manufacturing process and identify any weaknesses or potential problem areas. 
During this follow-up visit, students and Songhai staff tested local water supplies and the effectiveness of the filters. Samples of local well water, the Songhai Center (unfiltered) tap water, Pure ${ }^{\mathrm{TM}}$ treated water from the local market, and well water that was treated with the ceramic filters. Six ceramic water filters were randomly chosen from the Songhai Center's filter inventory for testing. Sample containers were prepared by cleaning with a dilute bleach solution, rinsing with filtered soapy water, and rinsed one final time with bottled water. All water samples were prepared using sterilized sample vials. The water samples were evaluated using presence absence methods with Hach test packets and prepared vials for total coliform bacteria, e. coli, and hydrogen sulfide producing bacteria (Pathoscreen ${ }^{\mathrm{TM}}$ ). The water samples were also evaluated for fluorescent bacteria, however, these tests could not be completed due to the failure of the UV lamps to function properly.

The results of the analysis are shown in Figure 4 and Table 3 below. It is important to note that none of the samples appeared dirty or contaminated to the naked eye. All water samples were clear of dirt and turbidity. All untreated water samples (well-water and tap water) indicated the presence of total coliforms, e. coli, and hydrogen sulfide producing bacteria, which are indicative of pathogen organisms and likely contamination by human or animal wastes. The treated water samples were all negative for all of the bacterial tests.

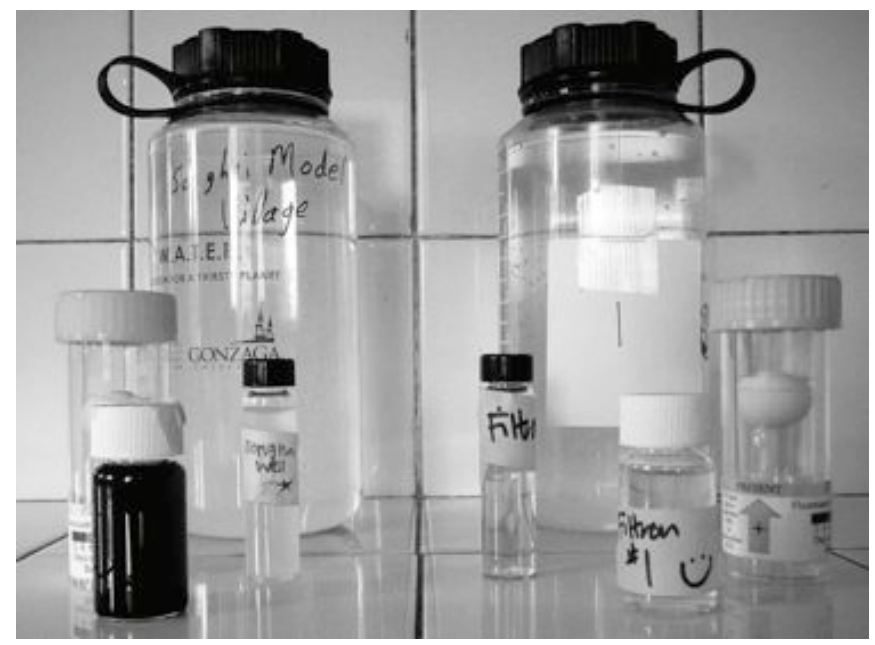

Figure 4: The original water samples are both clear and free from debris. However the analytical methods show bacteria contaminate the untreated water, while no contamination was observed in the filtered water. These samples also provide a visual method for demonstrating contamination of water that otherwise appears "clean" to the naked eye. 
Table 3: Presence of bacterial contamination in the untreated water samples compared to treated water samples.

\begin{tabular}{|l|c|c|c|c|}
\hline \multicolumn{1}{|c|}{ Source } & \multirow{2}{*}{\begin{tabular}{c} 
\# of \\
\cline { 3 - 5 }
\end{tabular}} & Samples & \multicolumn{2}{|c|}{ \# Indicating Bacterial Presence (Positive Result) } \\
\cline { 3 - 5 } & & $\begin{array}{c}\text { Total } \\
\text { Coliform }\end{array}$ & e. coli. & $\begin{array}{c}\text { Hydrogen Sulfide Producing } \\
\text { Bacteria (Pathoscreen }\end{array}$ \\
\hline Well Water & 4 & 4 & 4 & 4 \\
\hline Tap Water & 4 & 4 & 1 & 4 \\
\hline Pure ${ }^{\text {TM }}$ Water & 4 & 0 & 0 & 0 \\
\hline Filtered Water & 6 & 0 & 0 & 0 \\
\hline
\end{tabular}

The data in Table 3, while limited in scope, are consistent with results from previous testing of water in Benin and of filtered water both in the lab and in field tests of new filters. The ceramic filters perform very well as a point of use filter. The chemically treated Pure ${ }^{\mathrm{TM}}$ water was also free of bacteria. While both methods of treating the water appear successful, there are significant differences in the economic, cultural and societal impacts of the two technologies.

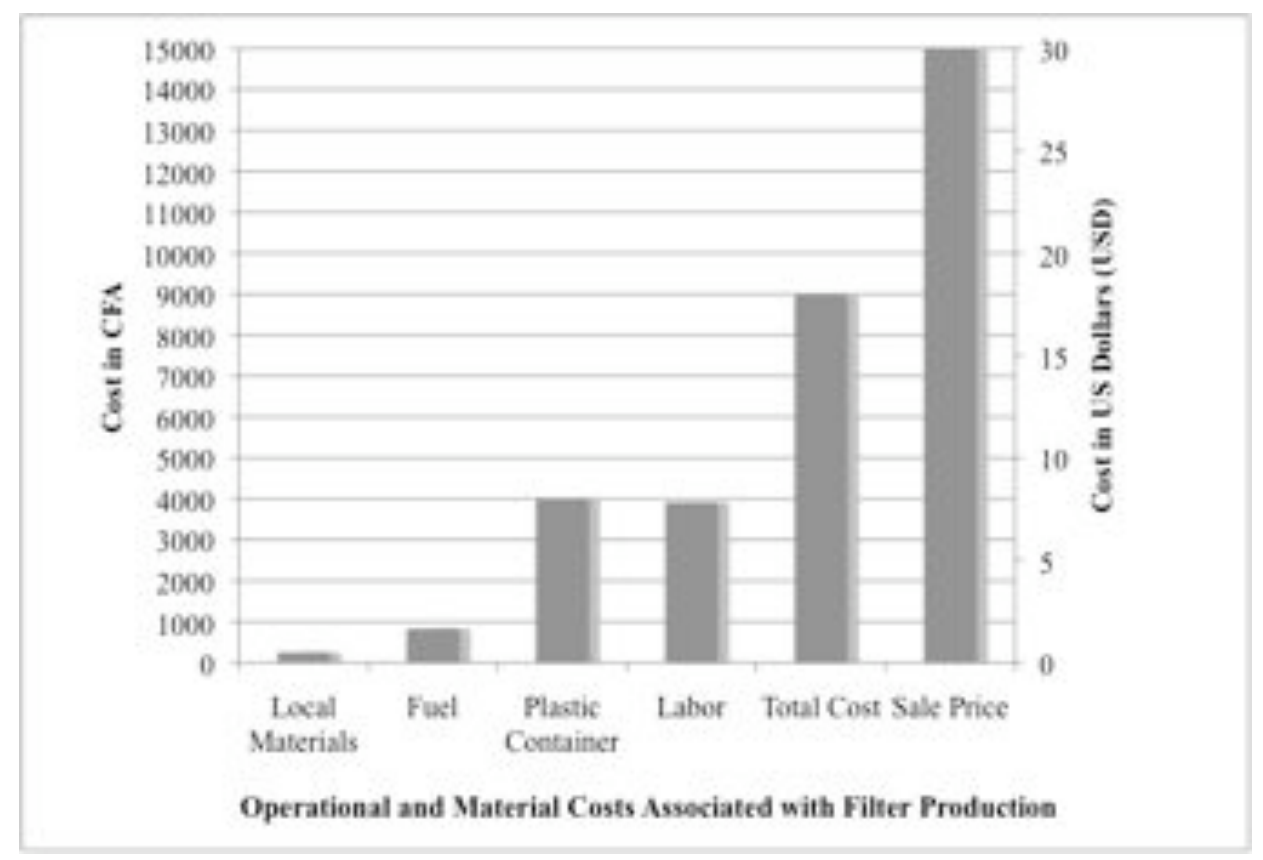

Figure 5: Local materials are sustainable since they have a low cost and need no transportation. The least sustainable piece of the filters are the plastic containers, since the require transportation and significantly impact the cost of each filter.

Field tests of ceramic filters reported in the literature indicate that the average lifespan of a filter is approximately 2 years. ${ }^{10,11}$ Also, if the filter is filled twice per day, it can easily be able to supply about 20 liters per day. ${ }^{5,10,11}$ (Actual maximum capacity is approximately 45 to 75 liters per day). The average household size in Benin is 6 family members who range widely in age. However, for comparing the costs of the methods, we have assumed only 4 members per 
household, which would provide a more conservative estimate of the daily water cost per household. The cost per liter of PureTM treated water in the local marketplace was 200 CFA ( 0.40 USD).

Table 3: Return On Investment (ROI) in a ceramic water filter compared to drinking bottled (or bagged) water available in the marketplace.

\begin{tabular}{|l|r|r|r|r|r|r|}
\hline $\begin{array}{c}\text { Treated Water } \\
\text { Type }\end{array}$ & $\begin{array}{c}\text { Liters per } \\
\text { day per } \\
\text { person }\end{array}$ & $\begin{array}{c}\text { Persons } \\
\text { per } \\
\text { household }\end{array}$ & $\begin{array}{c}\text { Purchase } \\
\text { cost } \\
\text { (CFA) }\end{array}$ & $\begin{array}{c}\text { Cost per } \\
\text { household per } \\
\text { day (CFA) }\end{array}$ & $\begin{array}{c}\text { Cost } \\
\text { per liter } \\
\text { (CFA) }\end{array}$ & $\begin{array}{c}\text { ROI } \\
\text { (years) }\end{array}$ \\
\hline Pure & 2 & 4 & 200 & 1600 & 200 & \\
\hline Ceramic Filter & 5 & 4 & 15000 & 20 & 1 & 0.21 \\
\hline
\end{tabular}

The economic savings for treated water are self-evident, for those able to invest in the technology. At the current sales price, using conservative estimates for water usage and household size, the filter would pay for itself in 0.21 years (less than 3 months).

Perhaps less evident are the societal ramifications. Children are rarely provided the treated water, since they are often in school. In addition, water consumption would likely increase, since clean water would be more easily available in the household. The health benefits due to consumption of clean water are well established and include, less likely to become sick, less severe symptoms during illness, and an overall healthier immune system. In addition to the economic benefits achieved directly from using more sustainable point-of-use treatment technologies, additional indirect economic benefits would accrue from having a healthier family. Ceramic filters would also cut down on resource consumption from the containers used for bottled beverages, creating less wastes.

Finally, as explained to us by Director Nzamujo, water plays an important part in Beninese society. Traditionally, all visitors were welcomed into a home with a cup of cool water. In urban and peri-urban areas, this traditional welcome has either ceased to exist, or is a pantomime of the original traditional Frequently, visitors may accept a glass, but only pretend to drink it In this way, the filter can be readily adapted into homes and traditional welcomes, since the water filters are easily identifiable and denote clean water. The ability to welcome people into a home in a traditional and respectful manner promotes the cohesiveness of society and helps promote public health. With these societal impacts in mind, the students of the WATER class adapted this societal message in preparing a special thank you gift for their friends in Benin.

In the follow-up visit, students were asked to directly address health education, first aid training and health marketing ideas with the Songhai staff. These issues were addressed again in small interdisciplinary working groups. One of the outcomes of these working groups was to set up a demonstration table to demonstrate to the public visiting the Songhai Center how the water filter worked. Songhai staff and program student's worked side by side again to set up the demonstration booth and to address the public, as the presence of white people distributing water created a positive curiosity about the ceramic filter product. 


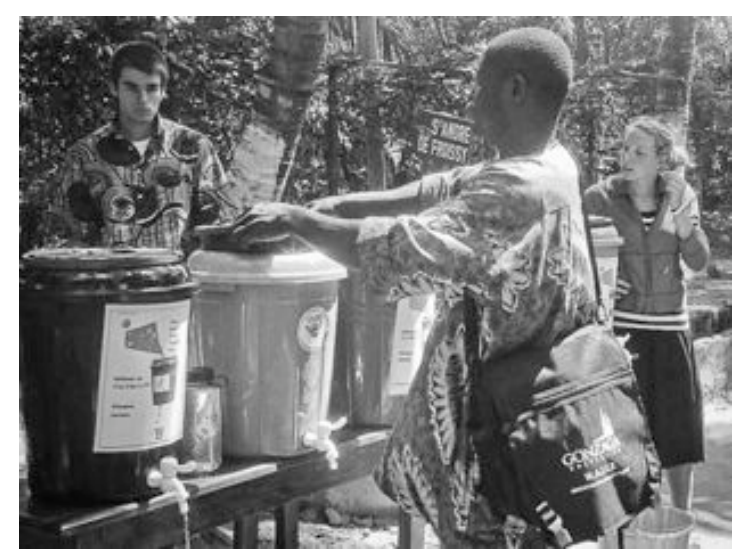

Figure 6: Students worked with Songhai Center staff to give away treated water samples and demonstrate the ceramic filters in the community.

\section{Educational Outcomes}

The unique opportunity presented is embodied in this quote from a recent Gonzaga engineering graduate after working in Africa as an undergraduate - she seems unlikely to leave her STEM field:

"What am I going to take away from this trip?... A new confidence in myself, in what I can accomplish, even the smallest things on this trip made me more proud than any award or report card ever has. From the fact that I came to Africa, to learning and working on my French, to convincing a man to buy a water filter for his family, or realizing my own capacity and future potential.” - Lauren Panasewicz, STEM student (Gonzaga '08).

Our experience with developing and implementing the WATER program has taught us valuable lessons about ourselves and our students and how we can interact and learn with members of other professions and another very different culture. It has taught us that everyone students/professionals from a wide variety of backgrounds and interests - has something they can contribute to this type of learning experience. We learned that perhaps our most profound role as course faculty is that of being a role model. We took very seriously our need to model the core values upon which the course was built and to model respect for one another as colleagues and professionals. We also have learned some very practical lessons that we believe can be helpful to other programs that are developing this type of experience.

First, visiting the proposed study site before beginning the course and program development process is essential. Secondly, we learned that communication is essential. It needs to be regular and ongoing with representatives of the study site, university administrators, and students, as well as between members of the faculty team. We have found there are real advantages to "frontloading" the academic component of the study abroad course so that students arrive at the study site with some knowledge and tools. We also have learned that there is no need to be intimidated by language differences. Gestures and drawing pictures are good communication strategies for students to learn - after all, even different professions speak different "languages" even when all speak English. 
Finally, we have come to realize just how important it is to have a real passion for the project. Those of us who have had the privilege to be involved in the WATER program would agree that it has been a profoundly enriching professional and personal experience. It has influenced our teaching and fueled our scholarship. Each year is different because the Songhai Centre articulates different needs - this means continuous course refinement. We are looking forward to returning to Benin in Summer 2009 with our third very diverse cohort of students and the third version of our course. Additional information about educational outcomes is presented elsewhere. ${ }^{9}$

Strong preliminary evidence from this program indicates both interest in graduate school, and post-BA STEM service. It provides real-world problems that students can address meaningfully, even as early undergraduates. Students, especially women, consistently report that these pragmatic and international components have encouraged them to stay in engineering, rather than changing to a non-science major. From 2004-08, some 53 GU science and engineering students participated in interdisciplinary courses abroad or in their capstone design course. Twenty-five (47\%) were women, compared to the usual 10-20\% of women in GU's "traditional" engineering programs. To date, GU has 38 graduates (14 women, 24 men) who participated in interdisciplinary, international development programs, including the WATER program in Benin. Six of them went to graduate school, 6 more have applied to graduate school and 6 went into full-time service work programs. These are 200-300\% the rates seen amongst non-participants. All the "full-time service workers" had taken the internationally focused design courses. All this suggests that for both men and women, a new problem-based, humanistic approach to engineering education can very significantly improve the likelihood that graduates will succeed in and remain in engineering, either via going to graduate school or doing service work.

Future work and hurdles to overcome

The WATER study abroad class has reached its enrollment for the summer of 2009 and plans are underway to return to Benin in July. Several problems have been identified that remain to be addressed jointly by Songhai Center staff, faculty and students. One problem is that the original kiln built to fire the filters is too small for the production scale envisioned by the Songhai Center. The Songhai Center is also experiencing supply issues with the plastic containers and spigots used to hold the filters and contain the filtered water. These supply issues have also made the filters more expensive than originally estimated. The plastic container parts make up approximately $45 \%$ of the overall cost of the filters. The filters are currently being sold for 15,000 CFA ( 28 US dollars) due in part to the limits of production and in part to the high costs of the plastic parts.

This years' group hopes to work with the Songhai staff to create a sustainable supply chain for all the components of the filter manufacturing process. This includes finding a less expensive and more reliable parts supplier and assisting with the design and construction of a new kiln. The partners will also continue to work on marketing strategies and building the health education capacity of the Songhai Center. Every trip also helps build and strengthen the relationship between the project partners.

Outcomes and assessment continue to be a challenge for a multi-disciplinary project-based course. Assessment methods are being evaluated and researched that may help quantify students individual gains and program outcomes. One challenge that remains particularly difficult is 
quantifying long-term impacts on cultural competency and life-long learning. The faculty have observed anecdotal information about these potential outcomes, however the group size and short length of the programs existence makes any conclusions very tenuous. A network of similar programs and projects to quantitatively assess these outcomes would be advantageous and necessary to demonstrate the long-term potential impacts of this and similar programs.

In addition to the service learning goals, we hope to build upon the longitudinal data that has so far shown increased interest in engineering, particularly among women. We also continue to track graduates and their application rates to graduate programs in engineering. Graduate school application rates for engineering students are significantly higher for students participating in the service-learning program, but more time is needed to fully understand the rate of graduate school application, acceptance, and completion. This data will continue to be collected for resent graduates and alumni of the WATER program.

\section{Conclusions}

One significant advance of the WATER program was the integration of an international service learning experience into the curriculum. Students were able to work on the service learning aspects of the project and incorporate their ideas into the capstone design projects, enhancing both the service-learning experience and the capstone design experience. The international component of the experience allowed students to increase their global awareness. Peer-to-peer presentations and experiences in small working groups (such as capstone design teams) help increase global awareness throughout the program, reaching beyond the students that participated in the program. The expectations of the WATER programs availability has lead to a stable and more sustainable implementation process for the technology transfer of the water filters. As a direct result of this project, several other international programs and projects have been developed.

Another very significant advance made by the WATER program was to demonstrate a working model for an interdisciplinary study abroad program. High academic standards, detailed but flexible assessment measures, and professional peer review has lead to a broad acceptance of the program and curriculum. This model has been used as a basis for new program development at two institutions. Students, faculty and outside reviews have all commented that the interdisciplinary nature of the program increases the likelihood of successful outcomes for the students and for the service-learning project.

Meeting the need identified by the project partner was one of the most satisfying outcomes of the program for everyone who was involved. Expectations of the students were very high and the experience was demanding. Students reported that the success of the project was an important motivating factor for the course and in their academic careers.

\section{References}

1. United States Agency for International Development (2008): http://www.usaid.gov.bj/health/index.html

2. UNICEF (2004) The Official Summary of the State of the World's Children

3. United Nations (2005) Water World Development Report: Water for Life, Water for People. 
4. World Health Organization (1993) Guidelines for drinking water quality, $2^{\text {nd }}$ edition: Volume 1, recommendations. Geneva, Switzerland.

5. Striebig, et. al. (2008) Activated Carbon Amended Ceramic Drinking Water Filters for Benin. Journal of Engineering for Sustainable Development. Volume 2. 1-11.

6. Butler, S. (2006) Benin. Bradt Travel Guides Ltd. UK.

7. United Nations (2000) Millennium Declaration: UN A/Res/55/2.

8. Bielefeldt, A. (2006) Attracting Women to Engineering that Serves Developing Countries." ASEE Annual Conference and Exposition, Conference Proceedings.

9. Norwood, S. and Striebig, B. (2009) WATER: A Model Partnership for Sustainable Development and International Education. Accepted for publication in the ASEE Annual Conference and Exposition, Conference Proceedings.

10. Brown, J. et al. (2008) Local drinking water filters reduce diarrheal disease in Cambodia: A randomized, controlled trial of the ceramic purifier. American Journal of Tropical Medicine and Hygiene. 79(3): 394-400.

11. Van Halem, et al. (2009) Assessing the sustainability of silver-impregnated ceramic pot filter for low-cost household drinking water treatment. Physics and Chemistry of the Earth. 34(1): 36-42.

More information about the program is available here: $\underline{w w w . m a c . c o m / w a t e r} \mathrm{dr}$

Acknowledgements

The authors would like to thank all those that contributed time, money and effort to the WATER program. The authors would like to acknowledge the efforts of the other faculty members for making this program possible especially Mary Jeannot, Mark Alfino, Jeff Hazen, Gary Weber, and the staff at Gonzaga University who support the related programs. The officers of EWBUSA and EWB-Gonzaga also played critical roles in the foundation and execution of the WATER program. This program is grateful for the grant support provided by the United States Environmental Protection Agency's People, Prosperity and Planet (P3) program. The faculty would like to express their appreciation to Julie Zimmerman and Cynthia Nolt-Helms for their dedication to the $\mathrm{P} 3$ program. Thanks also to all the many individuals not mentioned by name who contributed to the W.A.T.E.R. program.

The WATER program is also indebted to Ron Rivera of Potters For Peace and Burt Cohen of Potters Without Borders for their assistance and training that helped us learn how to make the ceramic water filters. We also appreciate the support of Rotary International for the program, in particular the members of Spokane's Rotary Club 21. The information and opinions expressed within the book are solely those of the authors and contributors and do not necessarily represent the opinions of program sponsors. 